\title{
Implementation of Corporate Social Responsibility in Islamic Banking in Indonesia
}

\author{
Sufyati HS
}

Universitas Nasional Jakarta, Indonesia

Email: sufyati.sufyati@upnvj.ac.id

\begin{abstract}
Corporate Social Responsibility (CSR) adoption in Indonesia demonstrates promising trends, with an annual growth. CSR is a strategy in which businesses incorporate social issues into their activities and relationships with customers on the basis of volunteerism and collaboration. Sharia Banking Law Number 21 of 2008 states that in addition to performing economic activities, it also contributes to the health of the people. Islamic banking can fulfill one of these goals through the practice of baitul mal, which is the receipt of funds from zakat, gifts, alms, or other public social funds. The aim of this analysis is to examine how CSR is implemented in Islamic banks in Indonesia. This research employs a descriptive qualitative approach to provide a more detailed description of the data. The thesis discusses the idea of CSR in Islamic banking, dubbed Al-Qardhul Hasan, which emphasizes collective empowerment projects as a means of educating the community about the importance of sustainable growth.
\end{abstract}

\section{Keywords: Corporate Social Responsibility (CSR), Islamic Bank, Community Empowerment}

\section{INTRODUCTION}

Corporate social responsibility has been a topic of discussion in business, politics, and culture for many decades (Brammer et al., 2012). Corporate social responsibility is a growing topic of discussion in the business world today. The recognition of the critical nature of corporate social responsibility motivates businesses to engage in CSR reporting. Numerous businesses in a variety of countries, including Indonesia, publicly announce their CSR activities. The CSR policy is an investment in the growth and survival of businesses and is no longer seen as an expense but as a way of benefit maximization. A company's CSR policy demonstrates its dedication to promoting sustainable growth (Hamann, 2013).

According to Nurlela (2008), CSR is a concept that frees businesses from obligations based solely on a single bottom line, namely corporate worth, as measured by the financial status (financial). However, the duty of the business must be focused on the triple bottom line, which requires commitment to social and environmental issues. Elkington believes that in order for a business to stay stable, it must consider the three Ps (benefit, people, and planet), namely that the business's objective should be not only profit, but also to make a meaningful contribution to society (people) and actively engage in environmental preservation (planet) (Alhaddi, 2015).
Companies that can express CSR well will provide positive feedback for the company. In gaining trust from various parties regarding the business being carried out, several companies are competing to provide the best value for internal and external parties by providing information that every behavior and action does not damage the creatures around them. Because in essence, when a company has received more value from various parties, it is not impossible that the company has become more advanced than before so that in the end, it can improve financial performance, raise the brand image, and increase attractiveness to the company as an excellent place to work (McWilliams \& Siegel, 2001). The practice of CSR disclosure has been carried out by publicly traded companies in Indonesia, which are generally engaged in mining or manufacturing because these companies have a higher risk of environmental pollution than other companies. However, in the end, CSR practices were followed by the banking sector (Fitria \& Hartanti, 2010).

The concept of CSR is also contained in Islamic teachings, which, when running a business, must be based on sharia principles and based on the basic philosophy of the Qur'an and Sunnah so that it becomes the basis for practitioners to interact with the environment and others. With this statement, it can be seen that Islamic institutions are more likely to pay attention to their environment well because the responsibility of Islamic institutions is not only to stakeholders but also to Allah SWT. In addition, 
Islamic institutions have a strong relationship between these institutions and their environment compared to non-Islamic institutions (Fauziah, 2013). Furthermore, Sofyani \& Setiawan explained that the perfection of a Muslim's faith could not only be achieved by a vertical relationship to Allah alone (Hablumminallah) - Individual piety but also must be accompanied by good relationships with fellow creatures created by Allah (Hablumminannas) social virtue (Sofyani \& Setiawan, 2012).

One of the institutions whose activities adhere to sharia values and are founded on the Al-Qur'an and Sunnah is the Sharia Bank, as the primary goal of creating a Sharia Bank is for Muslims to underpin all facets of their economic existence (Antonio, 2001). Islamic banking serves as a conduit for parties with surplus funds and those with insufficient funds to generate prosperity. exclusively financial and commercial transfers.

As with other facets of the Islamic way of life, the Islamic banking system serves as a method of achieving the Islamic social and economic system's objectives. According to Chapra, some of the fundamental objectives and functions of the Islamic banking system include the following: (a) expanding economic prosperity by full employment and optimal levels of economic growth; (b) socioeconomic justice and equitable distribution of income and wealth; and (c) maintaining the value of money in order for it to become a reliable unit of calculation, fa. According to Chapra, the Islamic financial and banking system is intended to lead to the achievement of Islamic socioeconomic goals in addition to offering halal financial services to the Muslim community (Chapra, 2000).

Islamic banks' social responsibilities align with the principle of Corporate Social Responsibility (CSR), which states that businesses should prioritize not only shareholder interests, but also the interests of stakeholders such as jobs, local populations, government, non-governmental organizations (NGOs), customers, and the environment (Rinovian, $\&$ Suarsa, 2018). Islamic banks, according to Meutia (2010), should have a stronger theological component. This spiritual component necessitates not only a non-interest-bearing enterprise but also the need to provide services for the broader population, especially the economically disadvantaged.

In relation to Islamic banks' social functions, in Indonesia, Islamic banks' social functions are wellknown in addition to their business functions. This is confirmed by the Sharia Banking Law number 21 of 2008 Article 4, which explains that Islamic banks have a social process and commercial operation. This is definitely consistent with the fundamental concepts of Islamic economics, which emphasize commercial objectives and emphasize the role of Islamic banks in promoting mutual welfare, which is a manifestation of the role of Islamic banks as executors of social functions. (Rambey, 2017).

In light of the above, the study's issue formulation is the degree to which corporate social responsibility transparency occurs in Islamic banks in Indonesia. It is hoped that this study will provide analytical data about Islamic banks' social responsibility disclosure practices, thus assisting in the advancement of Islamic banking social reporting practices and enriching the literature on Islamic banks' CSR disclosure in Indonesia.

\section{METHOD}

This research is qualitative research using the descriptive research method. According to Sugiyono (2009), it is a study to create a systematic picture, accruals regarding the facts, properties, and relationships between the phenomena being investigated, namely obtaining data describing or explaining the conditions that occur within the company. In qualitative research, the researcher is the main instrument in research because the researcher can see, feel, describe directly what is happening to the research object. The researcher can analyze the implementation following the theory that appears on the thing to be studied.

\section{RESULT AND DISCUSSION}

As with other facets of the Islamic worldview, the Islamic financial structure serves as a way of achieving the Islamic social and economic system's objectives. According to Chapra, some of the essential objectives and functions of the Islamic banking system include the following: (a) Expanding economic prosperity by full employment and optimal levels of economic growth; (b) Socio-economic justice and equitable distribution of income and wealth; and (c) Maintaining the value of money to allow it to become a reliable unit of calculation and a just $\mathrm{p}$ According to Chapra, the Islamic financial and banking system is intended to lead to Islamic socioeconomic objectives in addition to offering halal financial services to the Muslim population (Chapra, 2000).

As a growingly common term, CSR lacks a standardized definition. The following are some of the most influential and often referenced CSR objectives. CSR is a strategy in which businesses incorporate social issues into their activities and relationships with customers on the basis of 
volunteerism and collaboration. Additionally, many other words are synonymous with or often associated with the concept of CSR, like corporate charitable giving and philanthropy, as well as corporate community affairs (community development). Additionally, the four terms may refer to a layer or solution to corporate social responsibility in the form of corporate social investment, which is driven by a range of reasons ranging from "charity" to "empowerment." (Jamali \& Mirshak, 2007).

Even if it uses a variety of different words, it still points to the fact that the enterprise is an integral part of a corporate model that is closely linked to longterm business growth and can never be divorced from social and environmental responsibilities. Thus, CSR is a way for a business (corporation) to give back to the society (community). CSR will be accomplished in this situation by conducting and creating a company with the genuine goal of making the most beneficial contribution to the society (stakeholders) (Jamali \& Mirshak, 2007).

CSR discourse can be a parameter of the closeness of the era of civil society awakening. CSR is no longer limited to the philanthropic aspect, namely humanitarian motivation, which typically stems from universal standards and ethics to assist others and fight for social equity, but must crawl up to the macro and normal level of policy (policy). Therefore, this lies the importance of setting up CSR in Indonesia to have regulatory power, binding power and driving force. CSR, which was initially voluntary, needs to be upgraded to become a more mandatory CSR. With this characteristic, it is hoped that a measurable and systematic contribution from the business world improves people's welfare. Procommunity and environmental policies like this are urgently needed amid current neoliberalism (Sheehy, 2017).

Prince of Wales International Business Forum conveyed a more comprehensive opinion on CSR through five pillars: 1) Building human capital, regarding the company's ability to have reliable (internal) human resource support. Here, the company must carry out empowerment, usually through community development; 2) Strengthening economies, empowering the community economy; 3 ) Social assessing. This implies that the business works in accordance with the local society in order to avoid causing conflict; 4) Promoting sound governance. This indicates that the business is run by an outstanding civil service/bureaucracy; 5) Environmental protection, that is, the business must protect the environment.

There are four advantages of businesses applying CSR. To begin, the company's survival can be sustained, and the company gains a favorable reputation in the larger community. Second, it is easier for businesses to obtain money (capital). Thirdly, businesses should retain high-quality intellectual capital. Fourth, businesses may enhance their ability to make critical decisions and ease risk management.

At the moment, the duty to practice CSR is not limited to State-Owned Enterprises (BUMN). Legislation specifically regulates CSR structures. Corporate duty has been budgeted and estimated as an expense of the corporation under Law Number 40 of 2007 concerning Limited Liability Companies (PT Law) and Law Number 25 of 2007 concerning Investment (UU PM 13). Additionally, this policy governs penalties against businesses that fail to adhere to these commitments. According to Investment Law Number 25 of 2007, "any investor is required to practice corporate social responsibility." This definition states that "corporate social responsibility" refers to the inherent responsibility of every investment company to continue to create harmonious, balanced, and appropriate relationships with the environment, values, norms, and culture.

The language disparity between CSR as described in Law Number 25 of 2007 on Investment and Law Number 40 of 2007 on Limited Liability Companies makes it difficult for any business to translate into the technicalities of CSR implementation. This is because: (1) in Law Number 25 of 2007 on Investment, the terms "corporate social responsibility" and "inherent responsibility" are used; (2) in Law Number 40 of 2007, on Limited Liability Companies, the terms "corporate commitment" and "inherent responsibility" cannot be construed as synonymous with social responsibility; and (3) in Law Number 40 of 2007, on Limited Liability Companies, the terms "corporate commitment" and "inherent responsibility" cannot be construed as synonymous with social responsibility.

Additionally, when it comes to applying CSR, Law Number 25 of 2007 on Investment places no limits on the structure of the firm or its line of business. In comparison, CSR is specifically included in Law No. 40 of 2007 affecting Limited Liability Companies. Limited Liability Companies engaged directly in natural resources and related matters are required to fulfill social and environmental obligations, as specified in Article 74 paragraph (1), namely: "Companies that do business in the area of and concerning natural resources are required to fulfill social and environmental responsibilities."

Two points must be seen from the focal point outlined above: To continue, only businesses engaged in agricultural or natural resource-related activities are expected to demonstrate social and environmental responsibility. This is reinforced by Government 
Regulation No. 47 of 2012 on the Social and Environmental Responsibility of Limited Liability Companies, which states that "Companies, from now on referred to as Limited Liability Companies, are legal corporations that are capital alliances formed pursuant to an arrangement and carrying on business operations with fully approved capital. Divided into securities and complying with the provisions of Law No. 40 of 2007 on Limited Liability Companies and its implementing regulations "'. What is said by "companies that do business in the area of natural resources"? Are these businesses engaged in the management and use of natural resources? 24 Meanwhile, "companies that conduct commercial practices involving natural resources" refers to businesses that do not control or exploit natural resources. Nonetheless, their commercial operations have an effect on natural resource capability, including the maintenance of environmental functions. What is means by "depending on the statute" is the law and its implementing laws pertaining to natural resources or those related to natural resources, as well as the ethics of business management, which includes, but is not limited to, rules and regulations governing industry, forestry, oil and gas, and mining. Land, state-owned companies, geothermal energy, water supply, mineral and coal mining, power, environmental regulation and management, prohibition of monopolistic and unethical market practices, civil rights, labour, and consumer protection.

Concerning CSR, Islamic banking is a legal body governed by corporate law (Law No. 40 of 2007 on Limited Liability Companies), and it is governed by investment law in carrying out its CSR (Law No. : 25 of 2007, regarding Investment). The characteristics of a sharia banking system based on profit-sharing concepts provide an alternative banking system that benefits both the public and the bank, emphasizes elements of transactional justice and ethical investing, promotes virtues of togetherness and brotherhood in manufacturing, and avoids speculative financial transactions. Islamic banking has developed into a viable alternative to a reliable banking structure by offering a broader range of banking goods and services and more diverse financial schemes. It is open to all classes of Indonesian citizens without exception.

With the passage of Law No. 21 of 2008 on Islamic Banking, the development of a national Islamic banking industry would eventually gain a solid legal base, allowing it to grow even more rapidly. With its remarkable growth rate of more than 65 percent per year on average over the last five years, it is hoped that the Islamic banking industry's contribution to the national economy will become increasingly important.

Articles 2, 3 and 4 of In-Law Number 21 of 2008 on Sharia Banking demonstrate that Islamic banking seeks to promote national growth by rising justice, togetherness, and fair distribution of people's welfare. Islamic banking may fulfill one of these goals through baitul mal, which entails collecting funds from zakat, infaq, alms, or other social funds and distributing them to the public.

Islamic banking also offers al-qardhul Hasan lending items in addition to acquiring and selling zakat and waqf. This commodity falls under the category of Islamic banking social responsibility since it is not available via traditional banks. Thus, al-qardhul Hasan's funding as a social feature of sharia banks plays a critical role in advancing efforts to achieve people's wellbeing by Islamic economic instruments. To the extent that Islamic banking practices fulfill their social responsibilities by alqardhul Hasan financing, it is important to determine the extent to which these social responsibilities have been fulfilled. The qardhul Hasan financing ratio, or qardh ratio $(\mathrm{QR})$, is used to quantify the contribution of sharia banking to qardh financing. $Q R$ is determined by comparing qardh financing to overall Islamic banking financing. The greater this funding aspect, the more concerned Islamic banks are with parties in difficulty.

In addition, the social function of Islamic banking is seen through the Zakat Performance Ratio. The zakat or zakah ratio (ZR) performance ratio is used to measure the size of the company's zakat contribution issued by Islamic banking. In the AAOIFI standard, Islamic financial institutions are required for Bank Indonesia Thus, the implementation of the social function of Islamic banking can be measured by the amount of the social function implementation ratio (RFS) of Islamic banking. An assessment of Islamic banking's social function implementation ratio (RFS) is obtained by comparing qardhul Hasan financing and zakat payments with core capital or total equity. According to Bank Indonesia regulations, the higher the RFS component, the better the implementation of the social function of Islamic banking.

Furthermore, if it is related to implementing the corporate social responsibility (CSR) function in the community empowerment process, the Islamic banking Education Function Implementation Ratio (RPE) is used. As a form of implementation of the social part of Islamic banking, RPE is calculated and analyzed by comparing public education costs with the total operational costs. The cost of public education is reflected in the price of promoting Islamic banking. According to Bank Indonesia 
regulations, the higher the CSR ratio, the more significant the role of Islamic banks in the community empowerment process.

A form of CSR in Islamic banking is the alqardhul hasan program. The al-qardhul Hasan program is a social product in Islamic banking with the principle of helping to help. The al-qardhul hasan contract is a loan agreement between the lender (bank) and the other party provided that the loan recipient will return the loan at the agreed time with the same amount when the loan was given to benefit (maslahah) and the good of the community. . With this aim, Islamic banking will be called upon to provide loans to those who are classified as weak economies.

In this regard, the alqardhul hasan program aims to empower the community within the framework of an educational program for the general public. This community empowerment is primarily aimed at empowering the community's economy in a sustainable manner (sustainable economic development) to contribute to the country's economy. The product of al-qardhul Hasan is one of the characteristics that distinguish Islamic banks from conventional banks. As a characteristic of Islamic banking, it will improve the bank's image and increase public loyalty to Islamic banks. Thus, the alqardhul hasan program is one of the activities in realizing the social responsibility of Islamic banking following Islamic teachings.

\section{CONCLUSION}

The implementation of CSR in Islamic banking is usually known as the al-qardhul hasan program by emphasizing community empowerment programs within the framework of an educational program for the general public. In this program, as a form of Islamic banking, social responsibility is providing financial assistance that does not require a return. CSR implementation in Islamic banking can be a business strategy and a form of the company's contribution to sustainable development.

\section{REFERENCES}

[1] Brammer, S., Jackson, G., \& Matten, D. (2012). Corporate social responsibility and institutional theory: New perspectives on private governance. Socio-economic Review, 10(1), 328.

[2] Hamann, R. (2003). Mining Companies' Role in Sustainable Development: The'why'and'how'of Corporate Social Responsibility From A
Business Perspective. Development Southern Africa, 20(2), 237-254.

[3] Nurlela, I. (2008). Pengaruh Corporate Social Responsibility Terhadap Nilai Perusahaan Dengan Prosentase Kepemilikan Manajemen Sebagai Variabel Moderating. Simposium Nasional Akuntansi XI, 3, 23-26.

[4] Alhaddi, H. (2015). Triple Bottom Line And Sustainability: A Literature Review. Business and Management Studies, 1(2), 6-10.

[5] McWilliams, A., \& Siegel, D. (2001). Corporate Social Responsibility: A Theory of The Firm Perspective. Academy of Management Review, 26(1), 117-127.

[6] Fitria, S., \& Hartanti, D. (2010). Studi Perbandingan Pengungkapan Berdasarkan Global Reporting Initiative Indeks Dan Islamic Social Reporting Indeks. Simposium Nasional Akuntansi. Purwokerto. Proceeding.

[7] Sofyani, H., \& Setiawan, A. (2012). Perbankan Syariah Dan Tanggungjawab Sosial: Sebuah Studi Komparasi Indonesia Dan Malaysia Dengan Pendekatan Islamic Social Reporting Index Dan Globalreporting Initiative Index. Proceeding.

[8] Fauziah, K. (2013). Analisis Pengungkapan Tanggung Jawab Sosial Perbankan Syariah Di Indonesia Berdasarkan Islamic Social Reporting Indeks. Jurnal Dinamika Akuntansi, 5(1).

[9] Chapra, M. U. (2000). Sistem Moneter Islam. Jakarta: Gema Insani.

[10]Rinovian, R., \& Suarsa, A. (2018). Pengungkapan CSR Perbangkan Syariah sebagai Kebutuhan Informasi Stakeholder. Jurnal Ilmiah MEA (Manajemen, Ekonomi, \& Akuntansi), 2(2), 179-202.

[11] Meutia, I. (2010). Menata Pengungkapan CSR di Bank Islam (Suatu Pendekatan Kritis). Jakarta: Citra Pustaka Indonesia.

[12] Law Number: 21 of 2008 concerning Sharia Banking.

[13] Rambey, I. S. (2017). Analisis Pelaporan Corporate Social Responsibility (Csr) Perbankan Syariah Dalam Perspektif Shariah Enterprise Theory (Studi Kasus Pada Laporan Tahunan PT Bank Brisyariah Dan Pt Bank Muamalat Indonesia) (Doctoral dissertation, Universitas Islam Negeri Sumatera Utara).

[14] Sugiyono. (2009). Metode Penelitian Kuantitatif Kualitatif dan $R \& D$. Bandung: Alfabeta

[15] Jamali, D., \& Mirshak, R. (2007). Corporate Social Responsibility (CSR): Theory And Practice In A Developing Country Context. Journal Of Business Ethics, 72(3), 243262. 
[16] Ambadar, J. (2013). CSR Dalam Praktik Di Indonesia. Elex Media Komputindo.

[17] Sheehy, B. (2017). Conceptual and Institutional Interfaces Between CSR, Corporate Law And
The Problem Of Social Costs. Va. L. \& Bus. Rev., 12, 93.

[18] Asniwaty, B. (2010). Evaluasi Pelaksanaan Coorporate Sosial Responsibity CSR PT. Pupuk Kaltim. Jurnal Eksis, 6(1), 1267-1273. 